14 Dacie JV, Lewis SM. Practical haematology. 5th ed. Edinburgh, London and New York: Churchill Livingstone, 1975:198.

${ }^{15}$ McGavin CR, Gupta SP, McHardy GJR. Twelve-minute walking test for assessing disability in chronic bronchitis. $\mathrm{Br}$ Med 7 1976; :822-3.

${ }^{16}$ Butland RJA, Pang J, Gross ER, Woodcock AA, Geddes DM. Two-, six-, and 12-minute walking tests in respiratory disease. $\mathrm{Br} M e d \mathcal{F} 1982 ; 284$ 1607-8.

17 Willison JR, Thomas DJ, Du Boulay GH, et al. Effect of high haematocrit on alertness. Lancet $1980 ; \mathrm{i}: 846-8$.

${ }^{18}$ Cotes JE, Dabbs JM, Elwood PC, Hall AM, McDonald A, Saunders MJ. Iron deficiency anaemia: its effect on transfer factor for the lung (diffusing capacity) and ventilation and cardiac frequency during submaximal exercise. Clin Sci $1972 ; 42: 325-35$

${ }^{19}$ Clark EH, Wonds RL, Hughes JMB. Effect of blood transfusion on the carbon monoxide transfer factor of the lung in man. Clinical Science and Molecular Medicine 1978;54:627-31.
20 Harrison BDW, Gregory RJ, Clark TJH, Scott GW. Exchange transfusion with Dextran 40 in polycythaemia secondary to hypoxic lung disease. Br Med F 1971 ;iv:713-6.

${ }^{21}$ Roughton FJW, Forster RE. Relative importance of diffusion and chemical reaction rates in determining rate of exchange of gases in the human lung, with special reference to true diffusing capacity of pulmonary membrane and volume of blood in the lung capillaries. $7 \mathrm{Appl} \mathrm{Physiol}$ $1957 ; 11: 290-302$.

${ }^{22}$ Herbert JJ, Weill H, Stuckey WJ, Urner C, Gonzales E, Zisking MM Pulmonary diffusing capacity in polycythaemic states before and after phlebotomy. Diseases of the Chest 1965;48:408-15.

${ }^{23}$ Wallace D, Goldfinger D, Lowe C, et al. A double-blind controlled study of lymphoplasmapheresis versus sham apheresis in rheumatoid arthritis. $N$ Engl f Med 1982;306:1406-10.

\title{
Variation in the use of angiography and carotid endarterectomy by neurologists in the UK-TIA aspirin trial
}

\author{
UK-TIA STUDY GROUP
}

\begin{abstract}
Of 959 patients with complete records at entry to the UK-TIA Aspirin Trial 32\% underwent angiography; for the 27 neurologists with 10 or more patients in the trial this rate varied from $3 \%$ to $100 \%$. Seven per cent of the patients had carotid surgery; similarly the rate varied from $0 \%$ to $25 \%$ depending on the policy of the neurologist. These differences may be partly due to different perceptions of the safety and usefulness of carotid surgery. Ten of $41(24 \%)$ patients undergoing carotid surgery after randomisation had a perioperative stroke, and four of them died.
\end{abstract}

\section{Introduction}

Though carotid endarterectomy is frequently undertaken in patients with transient ischaemic attacks, whether or not it

Members of the study group: Dr A Downie, Dr J Hern (Aberdeen); D J Lyttle, Dr M Swallow (Belfast); Dr M Anderson (Birmingham); Dr M Campbell (Bristol); Dr R Ponsford (Coventry); Dr M Hutchinson, Dr E Martin (Dublin); Dr C Gardner-Thorpe (Exeter); Dr C Hawkes (Ipswich); Dr S Currie, Dr J Howe (Leeds); Dr P Millac, Dr I Pye (Leicester); Dr A Bowden, Dr D Chadwick (Liverpool); Dr M Gross, Dr P Monro (Atkinson Morley Hospital, London); Dr T Fowler (The Brook Hospital, London) Dr R Hughes, Dr S Mossman, Dr M O'Brien (Guy's Hospital, London); Dr C Allen, Dr M Harrison (Middlesex Hospital, London); Dr P Harvey, Dr L A Wilson (Royal Free Hospital, London); Dr D Thomas (St Mary's Hospital, London); Dr G Stern (University College Hospital, London); Dr A Lees (Whittington Hospital, London); Dr D Shepherd, Dr G Yuil (Manchester); Dr D Bates, Dr N Cartlidge, Professor D Shaw, Dr G Venables (Newcastle); Dr J Pilling (Norwich); Dr D Jefferson, Dr A Whiteley (Nottingham); Dr L Blumhardt, Dr C Davis, Dr R Greenhall, Dr N Hyman, Professor B Matthews, Dr C Warlow (Oxford); Dr D Thrush (Plymouth); Dr A Davies-Jones, Dr P Jackson (Sheffield); Dr B Burrell, Dr L Illis, Dr P Kennedy, Dr N Lawton, Dr L McLellan (Southampton); Dr R Weiser (Swansea); Dr J Rees (West Sussex); Trial Office, University Department of Clinical Neurology, Oxford. G Davey, $S$ Haines, $K$ McPherson, J McVittie, D Nassim, P Ogden, J Ratcliff, B Winsley; Clinical Trials Service Unit, Radcliffe Infirmary, Oxford A Daniels, B Hafner, $R$ Peto, S Richards; Clinical Audit Committee B Gribben, M Harrison, C Warlow; Policy Committee Professor P Armitage, University of Oxford, Sir Richard Doll, University of Oxford, Dr R R Russell, National Hospitals for Nervous Diseases, London; External Adviser Professor $M$ Gent, McMaster University, Hamilton, Canada. improves the long-term outcome beyond what may be expected from medical treatment is debatable. Since 1979 we have been collaborating in the UK-TIA Aspirin Trial, which is a doubleblind and randomised trial of two doses of daily aspirin $(600 \mathrm{mg}$ twice daily and $300 \mathrm{mg}$ daily) compared with placebo in the prevention of stroke and myocardial infarction after transient ischaemic attack. ${ }^{1}$ The individual policies of the participating neurologists on the value of angiography of transient ischaemic attack with a view to vascular surgery (usually carotid endarterectomy but occasionally a by-pass procedure) have varied greatly since the trial protocol neither encourages nor discourages angiography or carotid endarterectomy. Since the study group includes about one-third of all the practising consultant neurologists in the UK we believe that our wide divergences of opinion are worth examining in detail, particularly as our results with carotid surgery have been poorer than most other reported studies.

\section{Patients and methods}

Only the patients who have been randomised in the trial are reported here. The trial is continuing and the treatment allocation to aspirin or placebo is still unknown to the 56 neurologists entering patients from 30 centres. Patients aged 40 years or over with one or more transient ischaemic attacks* or minor stroke* in the three months before randomisation are eligible for the trial. The end-points are major stroke, myocardial infarction, and death; if these occur after the moment of randomisation they are accurately recorded. An entry form gives details of the cerebrovascular episodes, the result of angiography if carried out, and whether carotid endarterectomy was performed before randomisation. Follow-up forms giving end-points, whether

* A transient ischaemic attack is defined by acute focal neurological or ocular symptoms lasting less than 24 hours and thought to be due to vascular disease of an arterial embolic, or thrombotic kind. Minor strokes are defined similarly except neurological symptoms are allowable for up to one week, major strokes lasting for one week or longer. Neurological signs of no functional significance may be found after the resolution of symptoms and include asymmetrical deep tendon reflexes, extensor plantar response, nystagmus, unequal pupils and subjective cutaneous sensory impairment. Such sign probably depend on the period of time between the symptoms and examination, as well as on the skill of the examiner. It is important to stress that at the time of randomisation the patients, even in the minor stroke category, had no symptoms and therefore no disability or handicap. Patients with only non-focal neurological symptoms were not randomised: these include loss of consciousness, faintness, vertigo, imbalance, drop attacks, amnesia, and simultaneous bilateral visual disturbance. 
carotid endarterectomy was undertaken after randomisation, and other data not relevant here are completed every four months whether or not patients are still receiving trial medication. To avoid gross differences due to random variation in small numbers the rates for angiography and surgery are compared for only those neurologists with 10 or more patients in the trial.

Carotid surgery was undertaken only in patients with symptoms indicating a vascular disturbance within the distribution of the carotid artery. The "significance" of any lesion on angiography was assessed by the individual neurologists and their surgical colleagues; no attempt was made to operate on an occluded internal carotid artery, and usually, but not always, stenosis affected more than $50^{\circ}{ }_{0}$ of the diameter.

\section{Results}

At 14 May 1982 complete data had been coded, checked (in the computer) for plausibility, and where necessary corrected for 959 eligible patients.

Variation in angiogram rates-Angiography was undertaken at or near the time of randomisation in 304 of the $959\left(32^{\circ}{ }_{0}\right)$ patients. This rate varied from $3 \%$ to $100 \%$ for the 27 individual neurologists who had entered 10 or more patients in the trial (fig 1). This might have been because some neurologists randomised patients who were unsuitable for vascular surgery and therefore for angiography so table I shows some characteristics which might have influenced the decision to refer for an "angiogram with a view to surgery" by the three neurologists with the highest and the three with the lowest angiogram rates. There were no very substantial differences. We also analysed the angiogram rates in a subgroup of patients at low surgical riskthose who had had only transient ischaemic attacks and no residual neurological signs of any kind, whose vascular lesions had been in the territory of the carotid artery, and who were under 70 years old. Of 515 such patients, $235\left(46^{\circ}{ }_{0}\right)$ underwent angiography; though all would by conventional standards be particularly suitable for vascular surgery the angiography rates still varied greatly $\left(5-85^{\circ}{ }_{0}\right)$ (fig 2 ).

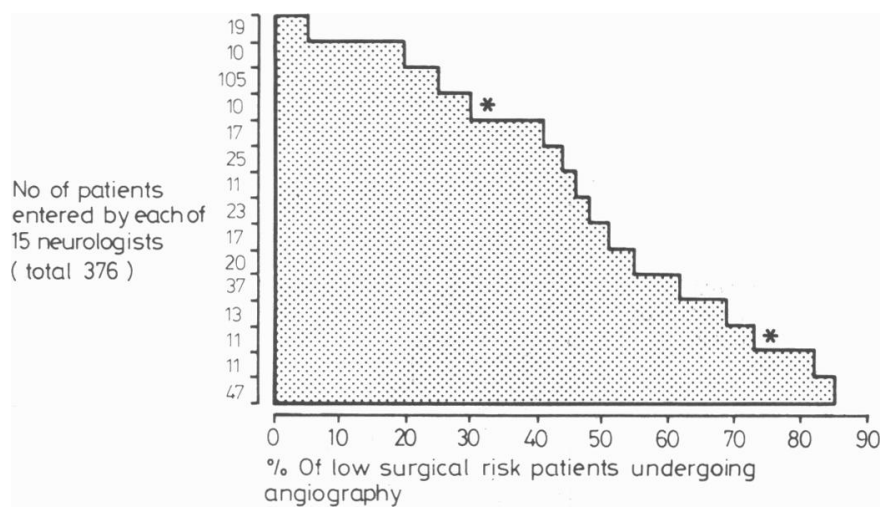

FIG 2-Angiography rates among 376 low surgical risk patients of 15 individual neurologists who had entered 10 or more such patients into the trial. (Asterisks-see fig 1.)

Variation in carotid surgery rates-Reconstructive surgery to the carotid artery was performed at some time in 67 of the $959(7 \%)$ patients; two patients had an extracranial by-pass procedure. Twentysix patients had surgery before randomisation and 41 after. Of the 27 neurologists with 10 or more patients in the trial 10 had not referred any patient for surgery; one of these 10 had randomised as many as 38 patients. The carotid surgery rate varied from 0 to $25 \%$ (fig 3). Even among the 15 neurologists who had entered 10 or more low surgical risk patients the rate still varied from $0 \%$ to $25 \%$ (fig 4); of 515 pat ients, $53(10 \%)$ underwent surgery.

Morbidity and mortality of carotid surgery-Because major strokes with residual disability excluded patients from entry to the trial any patient who had had a stroke either spontaneously or as a result of surgery or angiography before randomisation would not have been randomised and could not, therefore, be included in our analysis of trial end-points. We have accurate data on stroke, myocardial infarc-

TABLE I-Characteristics of patients seen by six neurologists with high and low angiography rates

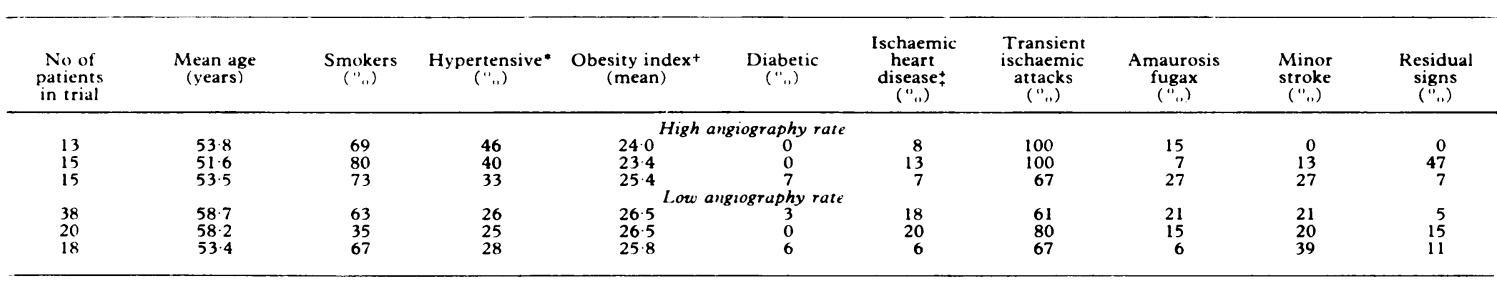

- Taking hypertensive agents or with a diastolic blood pressure (iv) $\geqslant 100 \mathrm{~mm} \mathrm{Hg}$ or both

+ Weight height ${ }^{*}\left(\mathrm{Kg} \mathrm{m}^{2}\right)$,
$\vdots$ Angina or past myocardial infarct or both

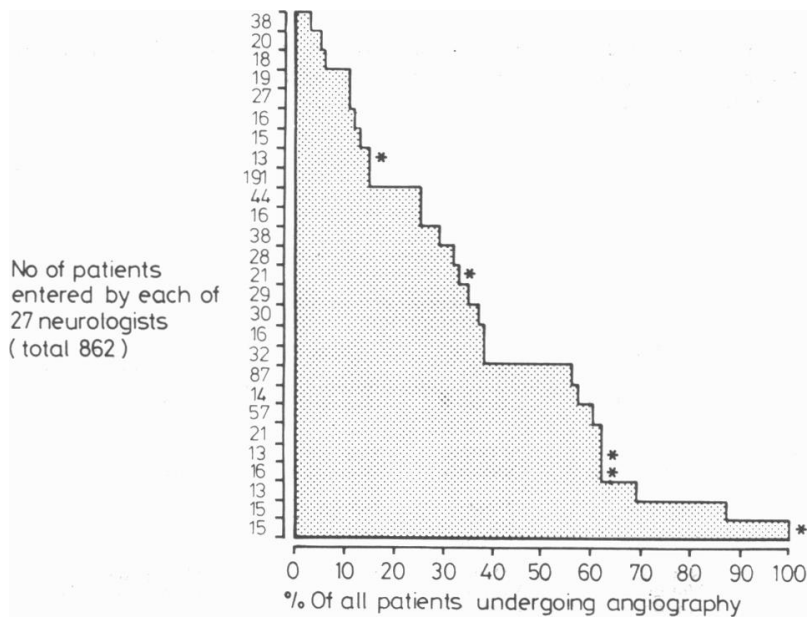

FIG 1-Angiography rates among 862 patients of 27 individual neurologists who had entered 10 or more patients into the trial. Asterisks refer to a neurologist whose trial patients may be unrepresentative of all their patiets with transient ischaemic attacks/minor strokes because of the medical policies of their surgical colleagues. tion, or death occurring after randomisation: 41 patients who underwent surgery at some time after randomisation had complications: $10(24 \% ; 95 \%$ confidence limits $11-38 \%)$ had a stroke as a result of surgery (table II); four died (as a result of perioperative stroke); two had a intracerebral haemorrhage; and two a cerebral infarction. The six surviving patients with strokes were substantially disabled two months after surgery; computed tomography was normal in two, the strokes presumably being due to small cerebral infarcts, and was not performed in four. The 10 patients had been entered from eight neurological centres.

\section{Discussion}

To determine whether daily aspirin reduces the risk of stroke, myocardial infarction, or death after transient ischaemic attacks or minor stroke we aim to have randomised about 2000 patients by 1 January 1984 and to examine several other interesting aspects of patients with transient ischaemic attacks.

We use angiography to delineate an operable lesion in the carotid arterial system in patients with symptoms referable to that artery ard seldom to diagnose transient ischaemic attacks or minor stroke, which are determined by the clinical features 


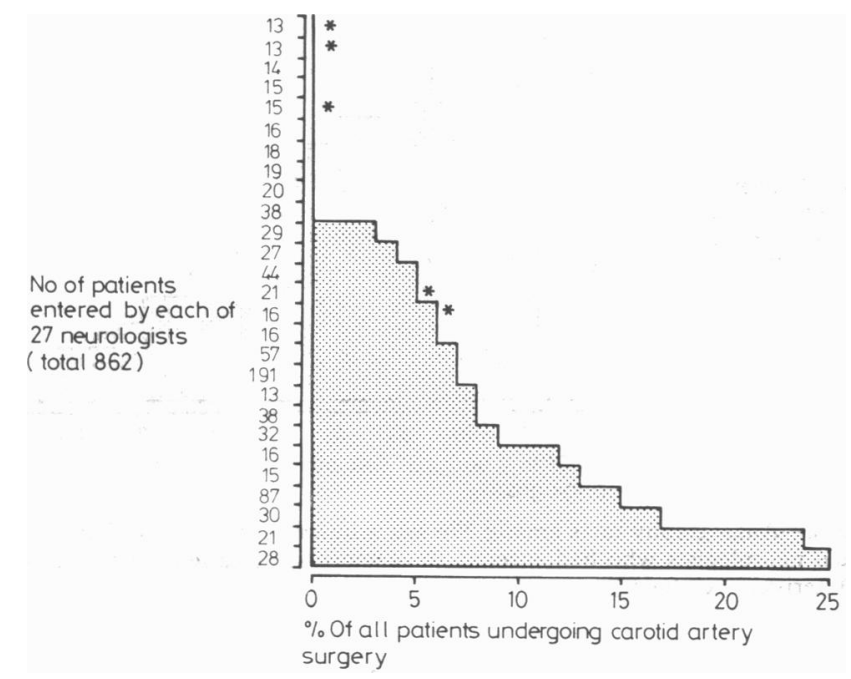

FIG 3-Carotid surgery rates among 862 patients of 27 individual neurologists who had entered 10 or more patients into the trial. (Asterisks-see fig 1.)

followed by less invasive and dangerous investigations. The risk of cerebral complications of angiography has varied from about $1 \%$ to $10 \%$ depending on the institution ${ }^{2}{ }^{3}$ and is therefore not a procedure to be undertaken lightly. Our angiography rate in the low surgical risk patients was $46 \%$ and compares with the rate of $59 \%$ among 400 patients with carotid transient ischaemic attacks in the Cooperative Study of Hospital Frequency and Character of Transient Ischaemic Attacks in the United States. ${ }^{4}$ This difference presumably reflects the more enthusiastic use of carotid surgery in the United States, though there may be differences between the two populations studied (for example, age, prevalence of prognostic variables for stroke, and degree of perceived surgical risk). Compared with that of the Cooperative Study of $33-91 \%$ among six neurological centres our variation in angiography rate of $0-85 \%$ was greater, perhaps reflecting a wider divergence of views of, and experience with, carotid surgery.

The variation in surgical rates was rather similar in the American Co-operative and our own studies $(6-35 \%$ in the former ${ }^{5}$ and $0-25 \%$ in the latter) though, overall, surgery was more often undertaken in the United States $(19 \%$ of 400 patients with carotid transient ischaemic attacks compared with $10 \%$ of our 515 low risk surgical patients). Exact demographic comparisons are impossible, but comparison of all the patients with transient ischaemic attacks in the American study with all the patients in our own study suggests that the former had a greater rather than lesser surgical risk and might, therefore, have been expected to have a carotid endarterectomy less frequently; the American patients were older (median age 63 versus mean age of 58.5), more often hypertensive $(52 \%$ v $38 \%)$ and diabetic प् $(18 \% v 4 \%)$, and had more ischaemic heart disease $(36 \% v$ $19 \%){ }^{6}$

Our large variation in angiography and carotid surgery rates does not appear to be the result of very different patient populations but probably reflects differing views on the use of surgery and possibly the availability of angiographic and surgical resources. Five of the 27 neurologists. with 10 or more patients in the trial work with vascular surgeons whose postoperative medical policy makes operative patients ineligible for the aspirin trial, usually because of an insistence on anti-platelet treatment. A low proportion of the trial patients of these five neurologists therefore probably undergo either endarterectomy or even angiography (their results are indicated by an asterisk in figs 1-4). Though the angiography rate is no lower than for the whole group the carotid endarterectomy rate is lower. This potential bias cannot, therefore, be wholly responsible for the total variation we observed. Nine of all the neurologists use some non-invasive technique to aid the angiography decision, but only six have 10 or more patients in the trial; the variation in their angiography rates was almost as large as that for the whole group $(5,20,30,41,73$, and $75 \%)$. Whatever the exact cause of the variation there is a very large difference in the management of a patient with transient ischaemic attacks depending on which neurologist is consulted. Either this variation makes no difference to the clinical outcome, in which case the surgical policy should be abandoned on the grounds

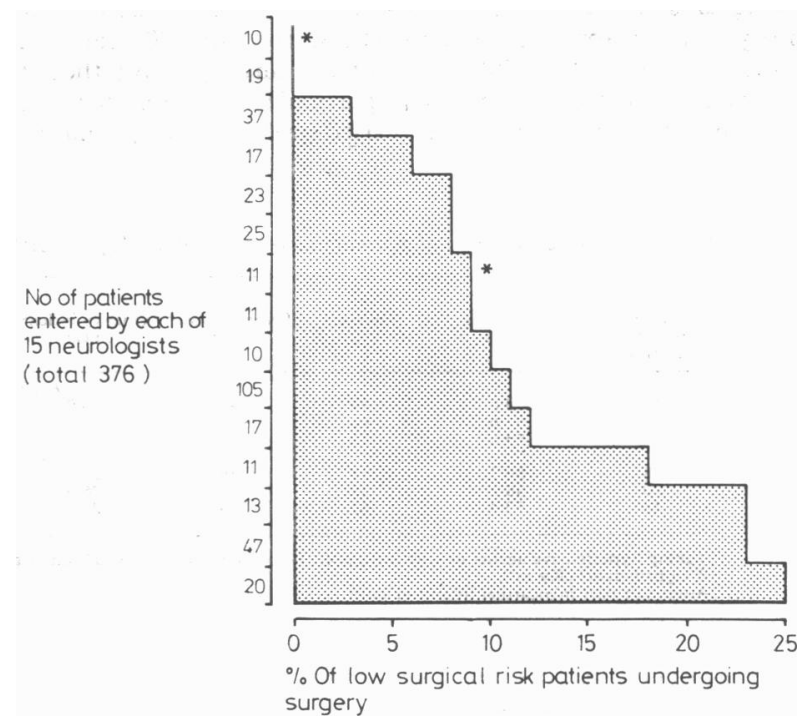

FIG 4-Carotid surgery rates among 376 low surgical risk patients of 15 individual neurologists who had entered 10 or more such patients into the trial. (Asterisks-see fig 1.)

TABLE II-Morbidity and mortality as a result of carotid surgery in eight neurological centres

\begin{tabular}{|c|c|c|c|c|c|c|c|c|c|c|c|}
\hline \multirow{2}{*}{ Centre } & \multirow{2}{*}{$\begin{array}{c}\text { No of } \\
\text { patients } \\
\text { in trial }\end{array}$} & \multirow{2}{*}{$\begin{array}{l}\text { Estimated } \\
\text { No of } \\
\text { endarter- } \\
\text { ectomies } \\
\text { performed } \\
\text { annually } \\
\end{array}$} & \multicolumn{5}{|c|}{ Details of patients (preoperative) } & \multicolumn{4}{|c|}{ Details of perioperative stroke } \\
\hline & & & $\begin{array}{c}\text { Age } \\
\text { (years) }\end{array}$ & $\begin{array}{l}\text { Indications for } \\
\text { carotid surgery }\end{array}$ & $\begin{array}{c}\text { Residual } \\
\text { signs }\end{array}$ & $\begin{array}{c}\text { Blood } \\
\text { pressure } \\
(\mathrm{mm} \mathrm{Hg})\end{array}$ & $\begin{array}{l}\text { Ischaemic } \\
\text { heart } \\
\text { disease* }\end{array}$ & CT scan & $\begin{array}{l}\text { Time of } \\
\text { onset }\end{array}$ & Cause ${ }^{+}$ & $\begin{array}{l}\text { Outcome at } \\
\text { two months }\end{array}$ \\
\hline 1 & 15 & 12 & 60 & $\begin{array}{l}\text { Transient ischaemic attacks, } \\
\text { amaurosis fugax, } \\
\text { minor stroke }\end{array}$ & Yes & $130 / 80$ & No & Haemorrhage & 1 Hour & Haemorrhage & Died \\
\hline$\frac{2}{3}$ & $\begin{array}{l}38 \\
16\end{array}$ & $\begin{array}{l}15 \\
10\end{array}$ & $\begin{array}{l}55 \\
58\end{array}$ & $\begin{array}{l}\text { minor stroke } \\
\text { Transient ischaemic attacks } \\
\text { Transient ischaemic attacks, }\end{array}$ & $\begin{array}{l}\text { No } \\
\text { No }\end{array}$ & $\begin{array}{l}140 / 80 \\
15095\end{array}$ & $\begin{array}{l}\text { Yes } \\
\text { Yes }\end{array}$ & $\begin{array}{l}\text { Infarct } \\
\text { Haemorrhage }\end{array}$ & $\begin{array}{l}24 \text { Hours } \\
\text { Operative }\end{array}$ & $\begin{array}{l}\text { Infarct } \\
\text { Haemorrhage }\end{array}$ & $\begin{array}{l}\text { Died } \\
\text { Died }\end{array}$ \\
\hline 4 & 27 & 3 & 62 & $\begin{array}{l}\text { amaurosis fugax } \\
\text { Transient ischaemic attacks, }\end{array}$ & No & 16090 & Yes & Not done & "Hours" & Not known & Dysphasia \\
\hline 5 & 28 & 11 & 61 & $\begin{array}{l}\text { amaurosis tugax } \\
\text { Transient ischaemic attacks, }\end{array}$ & No & $180 / 100$ & No & Not done & Operative & Not known & Hemiparesis, dysphasia \\
\hline$\frac{6}{7}$ & $\begin{array}{r}191 \\
57\end{array}$ & $\begin{array}{l}10 \\
12\end{array}$ & $\begin{array}{l}59 \\
56 \\
60\end{array}$ & $\begin{array}{l}\text { Amaurosis fugax } \\
\text { Minor stroke } \\
\text { Transient ischaemic attacks, } \\
\text { amaurosis fugax, minor } \\
\text { stroke, central retinal } \\
\text { artery occlusion }\end{array}$ & $\begin{array}{l}\text { No } \\
\text { Yes } \\
\text { Yes }\end{array}$ & $\begin{array}{l}140 / 90 \\
140 / 80 \\
160 / 100\end{array}$ & $\begin{array}{l}\text { Yes } \\
\text { No } \\
\text { No }\end{array}$ & $\begin{array}{l}\text { Not done } \\
\text { Not done } \\
\text { Not done }\end{array}$ & $\begin{array}{l}7 \text { Days } \\
3 \text { Days } \\
12 \text { Hours }\end{array}$ & $\begin{array}{l}\text { Not known } \\
\text { Not known } \\
\text { Infarct }\end{array}$ & $\begin{array}{l}\text { Monoparesis } \\
\text { Homonymous hemianopid } \\
\text { Died }\end{array}$ \\
\hline 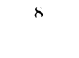 & 87 & 20 & $\begin{array}{l}54 \\
46\end{array}$ & $\begin{array}{l}\text { Transient ischaemic attacks } \\
\text { Transient ischaemic attacks, } \\
\text { amaurosis fugax }\end{array}$ & No & $\begin{array}{l}16090 \\
13075\end{array}$ & $\begin{array}{l}\text { No } \\
\text { No }\end{array}$ & $\begin{array}{l}\text { Normal } \\
\text { Normal }\end{array}$ & $\begin{array}{l}24 \text { Hours } \\
12 \text { Hours }\end{array}$ & $\begin{array}{l}\text { Infarct } \\
\text { Infarct }\end{array}$ & $\begin{array}{l}\text { Monoparesis } \\
\text { Monoparesis }\end{array}$ \\
\hline
\end{tabular}


of expense, if on no other, or in some centres patients are receiving more effective (or more dangerous) treatment than in others. Unfortunately no data confirm that carotid surgery definitely improves the outcome in these patients. The only randomised clinical trial was inconclusive since the apparent long-term benefit after successful surgery was balanced by the immediate risk of surgery. ${ }^{\text {? }}$

Our own differing attitudes towards carotid surgery and our concern that they are so very different have been highlighted by the overall risk of stroke and/or death in $24^{\circ}{ }_{0}^{\circ}$ of the 41 patients undergoing carotid surgery after randomisation. Our series is, however, small, the $95 \%$ confidence limits around the $24 \%$ risk estimate are quite large, and a population risk considerably below this figure remains plausible. Our results differ greatly from the risk reported in other papers, in which, with a few exceptions, ${ }^{8} 9$ the risk of stroke and/or death is under $10 \%$. If our findings truly reflect the general situation in Britain it is unlikely that the perioperative risk of stroke and/or death is better than the risk in non-operated but similar patients over several years of follow-up, the natural history studies of transient ischaemic attacks giving an approximate annual risk of stroke and/or death of $10^{\circ}{ }^{\prime} .^{\prime \prime}$ Possibly too few endarterectomies are being carried out in some centres to maintain an acceptable surgical mortality and morbidity and patients should be referred to other centres with more experience.

Some of us believe that if the surgical risk of stroke and/or death in our institution is less than about $5 \%$ patients with transient ischaemic attacks should be exposed to the risk of angiography with a view to carotid surgery. Others who have had unfortunate results with patients referred for surgery seldom recommend angiography. Still others hold views, more or less uncomfortably, between these two extremes. In fact, many in our group prefer randomly to allocate patients in the British and French carotid artery surgery trial which has recently begun in 16 institutions. We hope this trial will resolve some of the uncertainty surrounding the usefulness of the procedure, and we believe it is this very uncertainty which explains the enormous variation in our individual referral policies for angiography and carotid surgery.

This trial is supported by a special project grant from the Medical Research Council.

Correspondence should be addressed to: UK-TIA Trial Office, Department of Clinical Neurology, Radcliffe Infirmary, Oxford OX2 6HE.

\section{References}

${ }^{1}$ UK-TIA Study Group. Design and protocol of the UK-TIA aspirin study. In: Tognoni G, Garattini S, eds. Drug treatment and prevention in cerebrovascular disorders. Amsterdam: Elsevier, 1979:387-94.

${ }^{2}$ Faught E, Trader SD, Hanna GR. Cerebral complications of angiography for transient ischemia and stroke: prediction of risk. Neurology 1979; $29: 4-15$.

${ }^{3}$ Eisenberg RL, Bank WO, Hedgcock MW. Neurologic complications of angiography for cerebrovascular disease. Neurology 1980;30:895-7.

4 Swanson PD, Calanchini PR, Dyken ML, et al. A co-operative study of hospital frequency and character of transient ischemic attacks. $\mathcal{J} A M A$ $1977 ; 237: 2202-6$.

${ }^{5}$ Haerer AF, Gotshall RA, Conneally PM, et al. Co-operative study of hospital frequency and character of transient ischemic attacks. $7 A M A$ $1977 ; 238: 142-6$

${ }^{6}$ Dyken ML, Conneally PM, Haerer AF, et al. Co-operative study of hospital frequency and character of transient ischemic attacks. I. Background, organisation, and clinical survey. $\mathcal{f} A M A$ 1977;237:882-6.

${ }^{7}$ Fields WS, Maslenikov V, Meyer JS, Hass WK, Remington RD, MacDonald $M$. Joint study of extracranial arterial occlusion. V. Progress report of prognosis following surgery or non-surgical treatment for transient cerebral ischaemic attacks and cervical carotid artery lesions. FAMA 1970;211:1993-2003.

${ }^{8}$ Bouchier-Hayes D, De Costa A, MacGowan WAL. The morbidity of carotid endarterectomy. Br $\mathcal{F}$ Surg 1979;66:433-7.

- Easton JD, Sherman DG. Stroke and mortality rate in carotid endarterectomy: 228 consecutive operations. Stroke 1977;8:565-8.

10 Warlow C. Transient ischaemic attacks. In: Matthews WB, Glaser GH eds. Recent advances in clinical neurology. Edinburgh: Churchill Livingstone, 1982:191-214.

(Accepted 15 October 1982)

\section{SHORT REPORTS}

\section{Meningoencephalitis associated with Chlamydia trachomatis infection}

The recent increase in the incidence of non-specific genital infection has brought with it a growing awareness of Chlamydia trachomatis as a pathological agent at various sites. We report the first British case of meningoencephalitis associated with $C$ trachomatis infection.

\section{Case report}

A 23 year old heterosexual man who had never been abroad was admitted with a one-week history of fever, headache, and myalgia. Two days before admission he had developed confusion, unsteadiness on his feet, and urinary frequency. He admitted to several recent sexual contacts but these were untraceable.

On examination he was feverish with rigors and sinus tachycardia of 120 beats/minute. Cardiovascular and respiratory examination disclosed no further abnormality. Abdominal examination showed the bladder to be distended to the umbilicus. On rectal examination the prostate felt enlarged with general tenderness. External genitalia were normal. He was completely disorientated in time and space but responded to commands. He had neck stiffness, and Kernig's sign was present. On fundoscopy he had bilateral papilloedema. There was no dysphasia or focal motor signs. His gait was ataxic.

Investigations showed normal haematology and biochemistry. Radiography of the chest, skull, and lumbar spine showed no abnormality. Urine obtained by catheterisation contained many threads and debris with $10 \times 10^{6}$ white cells/l. No organism was cultured. The table shows results obtained at lumbar puncture. Prostatitis with septicaemia and secondary encephalopathy was diagnosed and cefotaxime begun.

A computed tomogram of the head showed small compressed ventricles, with the cisterns of the brain stem obliterated and the overall appearance compatible with generalised brain swelling with no localised lesion. Electroencephalography showed an 8-9 cycle/s symmetrical alpha rhythm with no focal abnormalities. Two further lumbar punctures were performed (see table). Urine specimens persistently showed a white cell count of 5-10 $\times 10^{6} / 1$ but no organism on routine culture. Six sets of blood cultures were sterile. Tests for Epstein-Barr virus, hepatitis B, mumps, measles, herpes simplex, herpes zoster, cytomegalovirus, enteroviruses, influenza $A$ and $B$, mycoplasma, leptospirosis, and heavy metal poisoning gave negative results.

Microimmunofluorescence antibody tests for Chlamydia performed on paired sera showed a 1/256 titre of immunoglobulin $G$ antibody to $C$ trachomatis $\mathrm{D}-\mathrm{K}$ rising to $1 / 1024$. There was no detectable $\mathrm{IgM}$ antibody. Cerebrospinal fluid yielded IgG antibody to $C$ trachomatis types $\mathrm{D}-\mathrm{K}$ at a

Results in cerebrospinal fluid obtained at lumbar puncture

\begin{tabular}{|c|c|c|c|}
\hline & Admission & At 10 days & At 20 days \\
\hline \multirow{4}{*}{$\begin{array}{l}\text { Red blood cells } \\
\left(\times 10^{6} / 1\right) \\
\text { White blood cells } \\
\left(\times 10^{\circ} / 1\right) \\
\text { Protein }(\mathrm{g} / \mathrm{l}) \\
\text { Glucose }(\mathrm{mmol} / \mathrm{l}) \\
\text { Culture } \\
\text { Ziehl-Neelsen stain } \\
\text { Fluorescence treponemal } \\
\text { antibody test } \\
\text { Immunoglobulin: } \\
\text { albumin ratio }\end{array}$} & 270 (traumatic) & 2 & 462 (traumatic) \\
\hline & $\begin{array}{l}\text { 9lymphocytes } \\
2 \cdot 3 \\
2 \cdot 8 \\
\text { No growth } \\
\text { Negative }\end{array}$ & $\begin{array}{l}208 \text { lymphocytes } \\
1 \cdot 21 \\
3 \cdot 0 \\
\text { No growth } \\
\text { Negative }\end{array}$ & $\begin{array}{l}1431 \text { ymphocytes } \\
0.52 \\
3.4 \\
\text { No growth } \\
\text { Negative }\end{array}$ \\
\hline & Negative & Negative & Negative \\
\hline & Normal & Normal & Normal \\
\hline
\end{tabular}

Conversion: SI to traditional units-Glucose: $1 \mathrm{mmol} / 1=18 \mathrm{mg} / 100 \mathrm{ml}$. 